\title{
Cultural Transduction and Adaptation Studies: The Concept of Cultural Proximity
}

\section{Patrick Cattrysse $^{1}$}

Recibido: 2016-08-25

Enviado a pares: 2016-08-25
Aprobado por pares: 2016-10-12

Aceptado: 2017-02-17

DOI: 10.5294/pacla.2017.20.3.3

Para citar este artículo / to reference this article / para citar este artigo Cattrysse, P. (2017). Cultural transduction and adaptation studies: The concept of cultural proximity. Palabra Clave, 20(3), 645-662. D0I: 10.5294/pacla.2017.20.3.3

\section{Abstract}

This paper looks at the concept of cultural proximity, as suggested by Joseph Straubhaar in his 1991 paper Beyond Media Imperialism: Assymmetrical [sic] Interdependence and Cultural Proximity. It argues that, based on a polysystem study of film noir adaptations from the early 1990s, both cultural proximity and distance may either enhance or inhibit the cross-cultural or cross-generic flow of media content depending on some specific conditioners such as the stability or instability (e.g., success or lack thereof) of the target genre or context and the conservative or innovating function of the adaptations in their target context.

\section{Keywords}

Adaptation studies; film adaptation; film studies (Source: Unesco Thesaurus).

1 orcid.org/0000-0001-8705-9264. Universiteit Antwerpen - Université Libre de Bruxelles. Belgium. patrick.cattrysse@telenet.be 


\section{Transducción cultural y estudios de adaptación: el concepto de proximidad cultural}

\section{Resumen}

El presente artículo examina el concepto de proximidad cultural, tal como lo sugiere Joseph Straubhaar en su artículo de 1991 "Beyond Media Imperialism: Assymmetrical [sic] Interdependence and Cultural Proximity". Se argumenta que, basándose en un estudio de polisistema de adaptaciones de film noir desde principios de los años noventa, tanto la proximidad cultural como la distancia pueden mejorar o inhibir el flujo cruzado de género o el flujo cultural cruzado de contenido de medios dependiendo de algunos acondicionadores específicos, como la estabilidad o la inestabilidad (por ejemplo, el éxito o la falta del mismo) del género o contexto objetivo y la función conservadora o innovadora de las adaptaciones en su contexto objetivo.

\section{Palabras clave}

Estudios de adaptación; adaptación cinematográfica; estudios cinematográficos (Fuente: Tesauro de la Unesco). 


\section{Transdução cultural e estudos de adaptação: 0 conceito de proximidade cultural}

\section{Resumo}

Este artigo analisa o conceito de proximidade cultural sugerido por Joseph Straubhaar em seu artigo de 1991, "Beyond Media Imperialism: Assymmetrical [sic] Interdependence and Cultural Proximity". Com base em um estudo de adaptações poli sistema de film noir desde o início dos anos noventa, argumenta-se que a proximidade e a distância cultural podem aumentar ou inibir o fluxo cruzado de gênero ou o fluxo cruzado cultural de conteúdo de mídia, dependendo de alguns condicionadores específicos, como a estabilidade ou instabilidade (por exemplo, o sucesso ou a falta de sucesso) do gênero ou contexto objetivo e a função conservadora ou inovadora de adaptações no seu contexto objetivo.

\section{Palavras-chave}

Estudos de adaptação; adaptação cinematográfica; estudos cinematográficos (Fonte: Tesauro da Unesco). 


\section{Introduction}

This paper looks at the concept of cultural proximity, as suggested by Joseph Straubhaar in his 1991 paper, Beyond Media Imperialism: Assymmetrical [sic] Interdependence and Cultural Proximity. The term was further developed by scholars and adopted into a wider research field, which Uribe-Jongbloed and Espinosa-Medina (2014) have coined cultural transduction. ${ }^{2}$ Cultural transduction studies aim to examine the exchange and trade of audiovisual practices and products between cultural markets. That trade is generally examined in the larger current setting of globalization. Scholars take their concepts, methods and data from literature on media imperialism and dependency theory, among other sources. However, in this chapter, I take on the view of (film) adaptation studies and look into the question of how cultural transduction studies could help descriptive adaptation studies and vice versa.

With respect to the traditional film adaptation studies, a cultural transduction approach offers more than one advantage. Firstly, it proposes to study the flow of media content in a descriptive way, rather than judgmental (Cattrysse, 2014). Secondly, it expands the analytical scope. Looking beyond the traditional source text-target text comparison, it studies wider trends and mechanisms conditioning adaptational phenomena. Following previous work in this field, researchers aim to complement traditionally textbased translation and adaptation studies with context-oriented approaches. They distinguish between processes and products, involve various codes and contexts, and also study more or less institutionalized agents (e.g., producers, consumers, distributors, postprocessors, receivers and prosumers) operating in "markets" (Uribe-Jongbloed \& Espinosa-Medina, 2014).

However, in doing so, these more recent studies, sometimes wittingly, sometimes unwittingly, continue or repeat much older proposals that were made in translation and adaptation studies. Rekindling some of these previous proposals may be interesting, especially in the field of adaptation studies, where many of them have remained underinvestigated (Cattrysse, 1990, 1992a, 1992b; Even-Zohar, 1978, 1979). And thirdly, the "trans-

2 Hjelmslev already suggested the term in 1943. It is also commonly used in genetics and biology. 
duction" paradigm adopts a multi-disciplinary approach, which provides a crossroads where various (sub) disciplines can meet and scholars can tap into cross-disciplinary concepts, methods and expertise. I mention adaptation studies, translation studies, cultural transfer studies, comparative cultural studies (including intertextuality and influence studies), (trans-)national and postcolonial cinema studies, political economy studies, intercultural communication studies, and convergence media studies.

\section{What is Cultural Proximity?}

Joseph Straubhaar (1991) coins the term cultural proximity to indicate forces that can oppose the one-directional flow of cultural imperialism. The author bases his claims on the observation that, in spite of cultural imperialist trends, audiences may prefer audiovisual programs from or about their own or a nearby culture.

However, scholars have soon realized that the concept of cultural proximity is too loosely defined (La Pastina \& Straubhaar, 2005; Ksiazek \& Webster, 2008; Uribe-Jongbloed \& Espinosa-Medina, 2014). To the extent that "culture" represents an umbrella term, audiences show complex (that is, composite) cultural identities, and cultural proximity plays at multiple regional, national and transnational levels. Groups of people may or may not share a language, ethnicity, religion, gender, profession, education, social class, dress, gestures, body language, definitions of humor, ideas about story pacing, music traditions, and so on. For example, La Pastina and Straubhaar (2005, p. 274) mention people from Idaho finding Seinfeld too much New York, or viewers living in rural and regional areas not identifying with elements of the so-called "national" culture, as shown on national TV.Consequently, researchers should not look for cultural proximity as one homogeneous phenomenon, but for a multitude of cultural proximities.

Furthermore, experts have soon discovered that, besides cultural proximity, other factors condition the intercultural exchange of audiovisual products. In other words, if cultural proximity is and remains the main challenger to imperialist flows of media content, other norms may make exceptions to this rule. Audiences may turn to media content produced outside 
their cultural environment if the content they are looking for is unavailable in their own environment (e.g., for lack of funds or expertise), or limited in terms of choice, or obsolete (La Pastina \& Straubhaar, 2005, p. 273; Rohn, 2011, p. 631). This concurs with previous findings published in the 1920s by Russian Formalists Boris Eikhenbaum, Yuri Tynjanov and Viktor Sklovsky with respect to literary evolution and the history of art more in general (Even-Zohar, 1990, pp. 23-25), and with findings appearing in the 1970s with regards to literary translation - see, for instance, the work of Itamar Even-Zohar $(1979,1990,2005)$ and Gideon Toury $(1980,1995)$ , and findings pertaining to film adaptation, appearing two decades later, in the 1990s (Cattrysse, 1990). ${ }^{3}$ If I rekindle these precursors, it is not to point out that these more recent studies bring old news. As a matter of fact, the world has changed since the 1920s, 1970s, and even the 1990s, and it makes sense to believe that the increased importance of globalization notably makes the role of cultural proximity stand out in a way that did not exist as such before. However, I contend that recalling this previous research may contribute to develop a more precise way to frame the role of cultural proximity and cultural distance in the flow of cultural goods across countries and cultures. In order to argue this point, I will discuss two particular cases where, at some point, cultural proximity inhibited rather than enhanced the flow of media content. Both are taken from a 1990s study of US film noir adaptations that were produced in the 1940s and 1950s (Cattrysse, 1990, 1992a, 1992b, 2014; henceforth the 1990 FNA study). The first case concerns the Gothic film noir, and deals with cultural proximity and censorship. The second case concerns the "tough-guy" detective film (1920s-1940s) and discusses cultural proximity related to film genre evolution.

\section{Cultural Proximity and Censorship}

From an adaptation studies point of view, the concept of cultural proximity recalls practices such as "periodization versus modernization," and "alien-

3 I must leave aside here the question of whether a study should focus rather on texts than on agents, makers rather than audiences (cf. the reader-response-criticism fashion of the 1980s), and the like. My view on this is that one can build an argument for all angles as interesting and relevant for one reason or another, and that no one can study them all at once. This joins the well-known issue of analytical relevance (Cattrysse 2014), which, among other things, depends on the purpose of the investigation and the (inter)-personal interest of the researcher(s). 
ation versus acculturation," or "foreignization versus domestication". For the reader who may not be familiar with these concepts: periodization refers to the adaptation process that transposes present-day stories into the past, while modernization does the opposite. Similarly, alienation or foreignization create a cultural distance between the adaptation and its target audience, while acculturation or domestication point to the reversed process of bringing the adaptation culturally closer to its target audience. Consequently, both modernization and acculturation involve cultural proximity, while periodization and alienation relate to cultural distance. Since culture represents a fuzzy category, "to acculturate" and "to alienate" may carry different meanings, depending on the investigated situation at hand. In this respect, the processes of periodization and modernization are less ambiguous.

Even though scholars in adaptation and intertextual studies have known about these practices for decades (Asheim, 1951, p. 294; Genette, 1982, p. 351ff; and Cattrysse, 1990, p. 219), a systematic historical study of what roles cultural proximity and cultural distance play in specific sets of film adaptations remains to be done. For example, literary scholar Gérard Genette (1982, p. 351) discusses proximization and distanciation in literature, and argues that the former is the more natural process. Within the field of film adaptation studies, Leitch (2007, p. 100) voices a similar assumption with respect to the adaptation of canonical literary texts to the screen. Previously, I have argued that, perhaps one should postpone such generalizing statements, pending a more consistent corpus-based research (Cattrysse, 2014, pp. 134-136). My skepticism is founded on findings made in the 1990 FNA study, and more in particular when considering one specific subset of films noirs called the "period" film noir or the "Gothic noir". Figure 1 presents a list of commonly mentioned "Gothic films noirs" (Hanson, 2007; Svetov, 2008, 2009).

Whereas the period film antedates the film noir, ${ }^{4}$ scholars agree that the cycle somehow innovates itself by moving into a darker world, represented also in 1940s films noirs (Borde \& Chaumeton, 1955, p. 60). Its most

4 Movies like Little Women (1933), David Copperfield (1935), Camille (1937), and Zaza (1938) already set in the trend in the 1930s (Karimi, 1976, p. 96). 


\section{Figure 1. List of commonly mentioned Gothic films noirs}

\begin{tabular}{|l|l|}
\hline 1940 Rebecca & 1945 Hangover Square \\
\hline 1941 Suspicion & 1946 Dragonwyck \\
\hline 1941 Dr. Jekyll and Mr. Hyde & 1946 Temptation \\
\hline 1941 Among the Living & 1946 The Spiral Staircase \\
\hline 1942 Kings Row & 1946 The Verdict \\
\hline 1944 Dark Waters & 1947 Ivy \\
\hline 1944 Bluebeard & 1947 So Evil My Love \\
\hline 1944 The Lodger & 1948 Moss Rose \\
\hline 1944 Gaslight & 1948 The Woman in White \\
\hline 1944 The Suspect & 1949 Reign of Terror \\
\hline 1944 Experiment Perilous & 1951 The Tall Target \\
\hline 1945 The Unseen & 1955 The Night of the Hunter \\
\hline
\end{tabular}

Sources: Cattrysse (1990); Hanson (2007); Svetov (2008, 2009).

productive period falls somewhere between 1944 and 1948, and the cycle expires in the 1950s. According to Svetov (2009), "The subgenre waned in the 1950s as the middleclass mindset pervaded American culture, leaving little room for period stories not concerned with the Old West or World War II" (p. 26). ${ }^{5}$

It should be clear that most films noirs represent stories that play in the present - that is, the United States in the 1940s or 1950s. "Period" films noirs represent stories that are set during Victorian or Edwardian England or America (mid-to-late $19^{\text {th }}$ century and early $20^{\text {th }}$ century). Even though of relative importance (24 out of a total population of 604 film noir titles, or, in other words, $3.97 \%$ ), the cycle consistently opts for cultural distanciation rather than cultural proximization. Indeed, the very selection of culturally remote stories, both in time and in space-many stories play in the UK-, signal cultural distanciation. No adaptation modernizes a novel. On the contrary, following upon the success of The Lodger (1944), Twentieth Century-Fox's Hangover Square (1945) actually periodizes Patrick Hamilton's novel, and transfers its story from the 1930 s into the $19^{\text {th }}$ century.

5 See also Borde and Chaumeton (1955, p. 63) on this. 
Film noir scholars have suggested that both self-censorship and restrictions imposed by the Hays Office ${ }^{6}$ may have advocated cultural distanciation rather than cultural proximization. I add two quotes that support this hypothesis. In his film noir study, Karimi (1976) points out that "at a time when the country's war efforts needed more self-assertive and encouraging themes, it was, perhaps, unwise to depict the gangland and its operators or to portray untrustworthy, discontented, and loveless Americans driven to violence by sex and money" (p. 96).

The second quote comes straight from the Hays Office, and is written by Joseph Breen:

\begin{abstract}
Law and order cannot be expected to prevail in the historic Wild West. It is evident, furthermore, that Shakespeare and Eugene O'Neill cannot be judged exactly alike. Again, the evil usages of a bygone age, no longer practiced, are not subject to the same critical examination as modern ways and customs. In general, historic and older classical subjects possess a certain quality of distance and unreality which mitigates effects that would be evil in a similar modern subject. (as cited in Moley, 1945, p. 100) ${ }^{7}$
\end{abstract}

Apparently, to the censors, immoral behavior could become acceptable if located in a far-away country (i.e., far from the USA) and in a "bygone age". The case of the Gothic film noir shows that cultural proximity is not always attractive. Whether an audience likes to look at itself in the mirror depends on the image the mirror is reflecting.

\title{
Cultural Proximity and Genre Change
}

A second case concerns a brief historical overview of the film adaptation of the hardboiled detective story in the US during the 1920s, 1930s and

6 The "Hays Office", named after its first president Will Hays, is the popular name for Hollywood's self-imposed board of censors. Founded in 1922, it is more accurately designated the Motion Picture Producers and Distributors of America (MPPDA). The MPPDA, later the MPAA (i.e. the Motion Picture Association of America), adopted in 1930 the so-called Production Code, stipulating what was acceptable and what was unacceptable content for motion pictures produced for a public audience in the United States. From 1934 to 1954, the code was closely identified with Joseph Breen, the administrator appointed by Hays to enforce the code in Hollywood (Moley, 1945; Gardner, 1987, pp. xv-xxiv; Leff \& Simmons, 1990, p. 33ff.).

7 See also Cattrysse (1990, p. 218-219; 270ff.). 
1940s. These data emerged from the aforementioned 1990 FNA study, which consisted in an experimental application of a "polysystem" study of adaptations (Cattrysse, 1990). ${ }^{8}$ Following a polysystem or descriptive approach in adaptation studies, one may study cultural proximity (or distance) on three levels or at three stages: the selection policy ("preliminary norms"), the actual adaptation policy ("operational norms"), and the structural or systemic correlations obtained between the two. Hence, this brief historical overview of the film adaptation of the hardboiled detective shows that the role of cultural proximity or cultural distance depends on a number of contextual factors, which can be localized at all three levels or stages. By way of example, I will now discuss the stability or instability of the target genre and the function of film adaptations, which can, for example, be either innovative or conservative. This particular case study shows that cultural proximity may inhibit or enhance the flow of media content depending on such conditioners.

\section{The literary hardboiled detective}

The literary hardboiled detective story emerges in the early 1920s when Carroll John Daly and Dashiell Hammett start their writing careers in pulp magazines like Black Mask. The genre takes a few years to develop but, when Captain Joseph T. Shaw becomes the editor of Black Mask in 1926, two explicit canons are established within the literary genre: Dashiell Hammett and Black Mask. The Black Mask School stands for a new type of detective story that reacts against the classical whodunit represented first by Arthur Conan Doyle's Sherlock Holmes and later by Dorothy Sayers' Lord Peter Wimsey and S.S. Van Dine's Philo Vance.

Speaking of cultural proximity, the tough guy detective really produces a cultural clash. With regards to the classical whodunit, it literally turns its world upside down. This tough guy variant involves much more violence and action than rational deduction and also more sadism and homoeroticism than the farfetched puzzle-like murders of the classical whodunit. If the classical whodunit presents a world that is neatly ordered and

8 More recently, the label "polysystem adaptation studies" has been replaced with "descriptive adaptation studies" (Cattrysse, 2014). 
occasionally disturbed by a murder or crime, the hardboiled detective story presents a society that is corrupt to the core, and occasionally, someone manages to do something right.

By the end of the 1920s, the hardboiled detective becomes quite successful and the genre catches the attention of some well-known publishing houses like Alfred A. Knopf in New York. In the 1930s, publishers encourage Hammett, Cain and Chandler to take up writing novels too. However, writing for this "more prestigious" genre means addressing different audiences. Writing for different audiences implies adapting or, in other words, applying self-censorship: less violence, less sadism, less homoeroticism, and less sex. For some writers, like Earl Stanley Gardner (as cited in Haycraft, 1983 [1946], p. 203, see, e.g., 1984 [1941], p. 213), this means the beginning of the end. Looking only at Raymond Chandler's writings, Marlowe becomes softer by the novel. Soon, readers and writers alike feel that the genre becomes repetitious. It has lost its verisimilitude, and is in urgent need of a change.

\section{The filmic hardboiled detective}

When looking at the film side of the genre, we notice that film noir scholars who discuss the literary origins of film noir generally mention the Black Mask School. However, during the 1920s, no Black Mask stories were adapted to the screen. One could assume that, during the first years, filmmakers did not know of the existence of the genre, but after 1926, when Captain Joseph T. Shaw enters the scene, the hardboiled detective has caught on with a growing (reading) audience. And yet filmmakers still did not touch the genre. Coming up with a full explanation would require a thorough study and extend the limits of this essay, but it is not hard to imagine that the morals displayed in these stories meant trouble, not only to the upcoming Hays Office, but to certain sections of the film audience as well. What is more, the talkative nature of the detective genre may explain why silent movies in these days preferred action-driven genres such as adventure stories, westerns and gangster movies. However, the coming of sound in the 1930s removes some of these technical problems, and the literary genre's migration from pulp to the more prestigious novel entails self-censorship 
and softens the hardboiled detective genre. This could have reduced at least some of the previous moral objections. However, the tough guy detective still does not take off in film. The 1931 and 1936 adaptations of Hammett's The Maltese Falcon merely represent two interesting exceptions I cannot further discuss here.

The dominant film genres of the 1930s are the gangster movie, the musical and the screwball comedy. Next to these more central genres the film detective emerges, but it builds on the classical whodunit formula rather than its hardboiled variant. Adaptations are made of Philo Vance (with William Powell), Ellery Queen (with Donald Cook and Eddi Quillan), Bulldog Drummond (by "Sapper" alias H. C. McNeill), the Saint (with George Sanders), some oriental detectives (such as Mr. Moto, Mr. Wong, Lone Wolf, Charlie Chan), the Thin Man, and others.

The central film detective of the 1930s is a sophisticated dandy who moves smoothly in a posh world of society nightlife. He leads a perfectly happy life, except for an occasional moment of boredom. Then a little murder or two come along his way and offer him a nice distraction between numerous cocktail parties, large quantities of champagne, and many available women. Rational deduction is often replaced by intuition or sheer luck, and on no occasion does the main character suffer any mental stress or is in any physical danger, let alone that of being brutally beaten, drugged and then left for dead in the gutter of some dark alley. Murder and crime merely serve as a context for a puzzle to be wittily solved. These stories do not criticize a corrupt society, they plea for a status quo. In that sense, their world represents the very opposite of the world of the hardboiled detective. One has to await the 1940s for the first hardboiled detective to appear in film.

In 1941, Warner Brothers' The Maltese Falcon announces a change without really launching a new run of hardboiled detective films. The gentleman detective remains active in the 1940s as well. After the success of the Saint, Georges Sanders continues with the Falcon. In 1939, Twentieth Century-Fox starts a series of Sherlock Holmes adaptations with Basil 
Rathbone and Nigel Bruce, and Charlie Chan also continues his exploits. It takes two more years for another tough guy detective, Philip Marlowe, to appear in American film noir: Murder My Sweet (1944). This film adapts Chandler's Farewell my Lovely and is followed by a mini series of Chandler adaptations: The Big Sleep (1946), The Brasher Doubloon (1946) (adapting The High Window again after the 1942 version Time to Kill) and The Lady in the Lake (1947).

Film historians Gardner (1987), and Leff and Simmons (1990) point out that filmmakers were well aware of the existence and success of these stories, but they suggest that the Hays Office played a decisive role in preventing Majors from adapting these stories to the screen. Hence, one has to wait until the war for a change in the political, cultural and moral climate. However, by then, the success of the literary hardboiled detective is already in decline. Parodies appear, such as My Favorite Brunette (1947), and suggest that both makers and audiences start to experience the genre's features as artificial. Consequently, the private eye is soon replaced either with the criminal protagonist or the victim-protagonist, that is, characters who are also socially oppressed, but have more personal, and thus more convincing reasons for fighting their way out of their predicament.

\section{Preliminary conclusions}

However embryonic this overview may be, it allowed already in the 1990s for some preliminary conclusions with respect to the role of cultural or genre proximity and distance in adaptation studies. The 1990 FNA study showed the following adaptational patterns or mechanisms:

- When the target genre was stable (i.e. successful), the function of the adaptations was conservative.

- When the target genre was unstable (i.e. unsuccessful), the function of the adaptations was innovative.

- When the function of the adaptation was conservative, the default selection of source materials consisted in selecting similar rather than dissimilar source materials, and the actual adaptation process tended 
to be more source than target (con)text-oriented. In traditional terms, fidelity to the source text prevailed. When, by way of exception, dissimilar source materials were selected, the actual adaptation process tended to change the source materials so as to align them more with the prevailing successful trends in the target genre. In other words, in those cases, fidelity was less relevant or not relevant at all. Hence, with respect to the subject of this essay, when the function of the adaptations was conservative, cultural or genre proximity was seen as an asset and cultural or genre distance rather as a liability.

- However, when the function of the adaptations turned innovative, the whole adaptational policy turned a full 180 degrees. Default selection of source materials consisted in selecting dissimilar rather than similar source materials, and the actual adaptation process once more consisted in faithfully adapting those dissimilar materials, i.e. in importing those exogenic or foreign elements in order to innovate the target genre conventions. If, by way of exception, similar source materials were selected, they were changed, that is, "unfaithfully" adapted so as to generically or culturally distance them from the current target context conventions in order to innovate the latter. Hence, when the function of the adaptations was innovating, cultural or genre distance was treated as an asset and cultural or genre proximity as a liability.

\section{Farewell My Lovely - The Falcon Takes Over - Murder My Sweet}

A good illustration of the mechanisms I just described can be found in two film adaptations of Raymond Chandler's novel Farewell My Lovely. One adaptation is called The Falcon Takes Over, which appeared in 1942. A second one is titled Murder My Sweet and came out two years later, in 1944. A comparison of the novel with these two adaptations illustrates the extent to which genre conventions (in terms of cultural proximity/ distance) affect adaptation choices. Chandler's novel continues the Black Mask School and the hardboiled detective genre with Philip Marlowe as the main character. 
By contrast, The Falcon Takes Over (1942) represents the third film in the Falcon series that continues the style and format of the 1930s series The Saint (Everson, 1972, p. 101; Luhr, 1982, p. 102). As I explained above, in transforming Marlowe into an aristocratic dandy, the movie turns his worldview upside down. However, the world changes in the early 1940s, and audiences grow tired of the gentleman detective. Film historian William Everson (1972) points out that "the [film detective] genre was in need of a massive jolt to restore it to box office favor. The jolt came somewhat unexpectedly with Murder My Sweet, introducing Philip Marlowe to the screen" (p. 230).

Consequently, the war years (1942-1944) seem to bring about a turning point. The 1944 version of Chandler's novel established the new mood that film noir was to become. It launched a mini-series of Marlowe and other private eye stories, reached its peak in 1946-1947 with films like Out of the Past, The Web and The Runaround, and disappeared rather quickly by the end of the 1940s (Everson, 1972, p. 235). The new private eye, Mike Hammer, who first appeared in the 1950s, is said to set off a new era of film detectives that are no longer considered to be part of the film noir cycle.

\section{Conclusion}

It is important to keep in mind that the adaptational mechanisms I just explained apply to the examined film noir adaptations only. In other words, in no way do these observations allow us to conclude that they would represent universal adaptational laws. As stated before, they do concur, however, with research conducted in literary translation in the 1970s by Itamar Even-Zohar. Whether and to what extent these mechanisms might be observed for example in other genres or in different historical contexts, are questions that require future empirical research. It is therefore safe $(\mathrm{r})$ to adopt a descriptive approach and to be careful with (over)generalizing statements. Taking a closer look at the game of cultural proximity and cultural distance in specific situations may offer a more detailed picture of its inhibiting and enhancing forces. And of course, the more cases one examines, the more evidence one gathers to support more generalizing statements. 


\section{References}

Asheim, L. E. (1951). From book to film: Simplification. Hollywood Quarterly, 5, 289-304.

Borde, R. \& Chaumeton, E. (1955). Panorama du film noir américain (19411953). Paris: Editions de Minuit.

Cattrysse, P. (1990). L'adaptation filmique de textes littéraires. Le film noir américain. Katholieke Universiteit Leuven, Leuven. Retrieved from http://independent.academia.edu/CattryssePatrick/Books

Cattrysse, P. (1992a). Film (adaptation) as translation: Some methodological proposals. Target. International Journal of Translation Studies, 4(1), 53-70.

Cattrysse, P. (1992b). Pour une théorie de l'adaptation filmique: Le film noir américain. Bern: Peter Lang International Academic Publishers.

Cattrysse, P. (2014). Descriptive adaptation studies: Epistemological and methodological issues. Antwerpen: Garant Publishers.

Even-Zohar, I. (1978). The position of translated literature within the literary polysystem. In Literature and translation: New perspectives in literary studies (pp. 117-127). Leuven: Acco.

Even-Zohar, I. (1979). Polysystem theories. Poetics Today, 1(1-2), 287-310.

Even-Zohar, I. (1990). Polysystem studies. Poetics Today, 11(1), 1-240.

Even-Zohar, I. (2005). Polysystem theory (Revised). In I. Even-Zohar (Ed.), Papers in culture research (pp.1-11). Tel Aviv: Porter Chair of Semiotics.

Everson, W. K. (1972). The detective in film. Secausus NJ: The Citadel Press. 
Gardner, G. (1987). The censorship papers. Movie censorship letters from the Hays Office, 1934 to 1968. New York: Dodd, Mead \& Company.

Genette, G. (1982). Palimpsestes. La littérature au second degré. Paris: Éditions du Seuil.

Hanson, H. (2007). Hollywood heroines. Women in film noir and the female gothic film. London, New York: I.B. Tauris \& Co Ltd.

Haycraft, H. (ed.) (1983 [1946]). The art of the mystery story. New York: Carroll \& Graf Publishers.

Haycraft, H. (ed.) (1984 [1941]). Murder for pleasure. The life and times of the detective story. New York: Carroll \& Graf Publishers.

Karimi, A. M. (1976). Toward a definition of the American film noir (19411949). New York: Arno Press.

Ksiazek, T. B. \& Webster, J. B. (2008). Cultural proximity and audience behavior: The role of language in patterns of polarization and multicultural fluency. Journal of Broadcasting \& Electronic Media, 52(3), 485-503.

La Pastina, A. C. \& Straubhaar, J. D. (2005). Multiple proximities between television genres and audiences: The schism between telenovelas. International Communication Gazette, 67(3), 271-288.

Leff, L. J. \& Simmons, J. L. (1990). The dame in the kimono. Hollywood, censorship, and the production code from the 1920s to the 1960s. New York: Grove Weidenfeld.

Leitch, T. (2007). Film adaptation of its discontents. From gone with the wind to The Passion of the Christ. Baltimore: John Hopkins University Press. 
Luhr, W. (1982). Raymond Chandler and film. New York: Frederick Ungar Publishing.

Moley, R. (1945). The Hays Office. New York: The Bobbs-Merril Company.

Rohn, U. (2011). Lacuna or universal? Introducing a new model for understanding crosscultural audience demand. Media Culture Society, 33(4), 631-641.

Straubhaar, J. D. (1991). Beyond media imperialism: Assymetrical interdependence and cultural proximity. Critical Studies in Mass Communication, 8(1), 39-59.

Svetov, M. (2008). Beyond the fedora: Part one. Noir and the gothic. Noir City Sentinel, Oct./Nov., 8.

Svetov, M. (2009). Beyond the fedora: Gothic noir. Second of two parts. Noir City Sentinel, July/Aug., 26-27.

Toury, G. (1980). In search of the theory of translation. Tel Aviv: Porter Institute.

Toury, G. (1995). Descriptive translation studies and beyond. Amsterdam: John Benjamins Pub. Co.

Uribe-Jongbloed, E. \& Espinosa-Medina, H. D. (2014). A clearer picture: Towards a new framework for the study of cultural transduction in audiovisual market trades. Observatorio, 8(1), 23-48. 